\title{
CONSERVATION AND ENJOYMENT OF SPANISH NATURE PARKS. A PROPOSAL FOR THE MANAGEMENT OF PUBLIC USE
}

\author{
Justo García Navarro, Vincenzo Giovanni Mennella, Marco Vizzari
}

\section{Introduction}

An historical and bibliographical research into the regulatory and practical relevance of natural parks in Spain has contributed to the investigation and critical analysis of the evolution of these protected areas.

In 1975 many protected areas in Spain were declared "Nature Parks". However, conceptual weaknesses in the definition of this designation, as well as shortcomings in their establishment, led to their elimination as legal entities under Law 4/1989 dealing with the conservation of protected areas and their flora and fauna. Even though these "Nature Parks" no longer exist in legal terms, the protected areas described still do. Some, in fact, even retain this old epithet in their current name. Law 4/1989 defines the term 'Park' as "an area little modified for the purpose of human exploitation or occupation and which, given the beauty of its landscape, the nature of its ecosystems or the uniqueness of its flora or geomorphological formations, is of ecological, aesthetic, educational or scientific value deserving of special attention."

According to the 1994 IUCN classification, "a protected area" is defined as an area of land and/or sea especially dedicated to the protection and maintenance of biological diversity, and of natural and associated cultural resources, managed through legal or other effective means [14]. This broad definition of protected areas includes several categories, such as, among others, total protection, referred to Strict Nature Re-

Paper received 18.05.2006; accepted 26.06.2007

Justo García Navarro, Full Professor. Department of Construction and Rural Roads, Polytechnic University of Madrid.

Vincenzo Giovanni Mennella, Full Professor, "Uomo e Territorio" Department, University of Perugia.

Marco VizZari, Post-Doc Researcher, "Uomo e Territorio" Department, University of Perugia.

This research is the result of collaboration with equal contributions by the authors. It represents a product of the research program "The Natural Parks of Spain: Their Conservation and Enjoyment", which was awarded with the Alfonso Martín Escudero Prize. The work has been carried out inside the cultural framework agreement between University of Perugia and Polytechnic University of Madrid. serves, ecosystem protection and tourism including Nature and National Parks, or the conservation of natural characteristics, referred to Natural Monuments. The essential aspect of all these categories is that the area has to be managed in such a way as to ensure long-term protection of its biodiversity.

The category being analysed here, that of "Nature Parks" is conceptually broader and less restrictive than that of National Parks. While the later cover relatively large surface areas, becoming protected areas due to their qualified natural values (including landscape resources) and with the main aim of facilitating contacts between man and nature, a Nature Park, on the other hand, enables reasonable use, within certain limits, of the various resources. Consequently, one of the main aims of a Nature Park is to harmonize the preservation of environmental values with the orderly exploitation of resources. At the same time, enjoyment and public use must be combined in such a way as to endeavour to maintain the original state of the area.

In the IUCN classification it is implied that public use is considered a form of managed use of an area and a tool for stimulating income increasing of the local population [3]. Consequently Spanish Nature Parks correspond, to a great extent, to the category defined by the IUCN as Protected Landscape/Seascapes since they are identified with areas in which the methods of traditional exploitation by man have produced ecosystems of great beauty associated with a rich biodiversity.

The functions of Nature Parks should be: the conservation of nature, facilitating public use of the area by visitors and enabling rural development of existing villages. Consequently, the basic goal of planners and managers of a protected area is to make these functions compatible. This is a worldwide problem and has always been a key issue for park managers and planners. Limiting the use of natural resources and/or prohibiting activities that are incompatible with the status of protected areas has now become one of the main issues for park managers. Noe et al. [18] have analyzed this problem in three national parks in the southeastern United States while White and Lovett [20] have investigated the need to charge a fee for vis- 
itors to National Parks in the U.K. in order to provide additional revenue for nature conservation and recreation in the Parks.

Nearly thirty million people visit Spain's protected areas every year, showing clearly that they are an important public attraction. Public use has been part of the very concept of Nature Parks since they were first conceived in the USA, and a central idea alongside that of conservation. The recent definition of 'public use' by EUROPARC-España moves in the same direction: "The facilities, activities and services that, regardless of who manages them, should be provided by the administration of the protected area in order to inculcate in its visitors the necessary values [of conservation]..." [8].

Taking stock of the resources offered by a natural area, followed by their assessment and analysis, is the starting point for the conservation of a protected area. During the initial application of Law 4/1989, between 1989 and 1992, 32 Parks and 24 Reserves were established. The first four Natural-Resource Plans (NRP) were approved in 1992, but the original idea that such plans be available before a Park be established did not become the practice until very recently. According to the EUROPARC-España Technical Department [12], this reflects the historical lack of means for the protection of natural resources and conservation. In 1994, with the multiplication of the number of protected areas, 46 new NRPs were approved. In 1999 there were 138 declared Parks (12 National Parks and 126 Nature Parks), but only 60 (about 43\%) had NRP's in place.

Regarding the actual landscape-planning and protected areas system, two events were key in the conception and developing culture of nature conservation. The first was the introduction of the United Nations Biodiversity Treaty at the UN Conference on Environment and Development in Rio de Janeiro in 1992. The countries that signed the Treaty undertook to develop strategies, plans or programmes for the sustainable managment of biodiversity. It was proposed that the signatories set up a system of protected areas in which special measures would be taken to conserve biodiversity, and where natural ecosystems and habitats would be protected. Spain ratified the Treaty in 1994. The second key event was the publication of European Directive 92/43/EEC of the European Council of 21st May 1992, concerning the conservation of natural habitats and wildlife (hereafter referred to as the Habitat Directive). Since this year it has been possible to speak of a modern concept of planning for protected areas with an integrated, global perspective.

The idea of preserving 'natural islands', first spoken of in 1962, and the concept of conservation based on the idea of "glass vases" free of human activity (a model of conservation in which protection meant prohibition) are now seen as hopelessly inefficient. Thirty years later, the planning and management of protected areas was being approached from a radically different perspective, i.e. considering them as part of an environment in whose natural, social and economic dynamics they participate [6].

The Habitat Directive understood the need to abandon the isolationist model of conservation, in which planning strictly affected the protected area alone. The new model of landscape planning considered the territory as an integrated system and focused on the influence of human activities on the protected area. A further step was then taken which integrated these different areas into a network with the aim of encouraging their conservation, and eventually allowing their biological connection and physical continuity. The idea was to overcome the concept of "islands of protection" and allow organisms to move from one protected area to another through natural or anthropogenic corridors [15]. These links, often called ecological corridors, together with core areas and stepping stones, constitute the main elements of ecological networks [9]. In this context, environmental continuity and biopermeability play a very important role, emphasizing the level of fragmentation of habitats and the hampering effect of human settlements and infrastructures [11].

Today, the ideals defended by the Habitat Directive are well understood and are more or less practised by the majority of EU Member States. In Spain, most of the autonomous regions have already planned network structures for their protected areas and have passed the appropriate legislation, although a national network that integrates and coordinates them all is still to be developed.

In any case, the protection provided for natural areas following normative designation is only passive, limiting or preventing activities that might lead to degradation. Such measures can only define an area of land where attempts can be made to maintain the natural equilibrium and biodiversity. More direct action is required and other types of planning are needed in order to achieve active management of resources (active management being understood to mean: a management plan with identified goals and supported by sufficient material and human resources to attain them).

\section{Materials and methods}

With reference to the topics presented in introduction, this study focused on the development of the basic instruments for managing Spain's Nature Parks, with a special focus on management related to public use. In this context, different elements involved in the management process for public use of Nature Parks are investigated. This has allowed a management model to be developed which can combine conservation and sustainable development of landscapes. The methodology is based on the analysis of the main instruments and planning criteria regarding Spanish Parks constituting reference elements for defining of a sustainable management model of public use.

With regard to the organisation of defined natural 
areas, the basic planning instrument defined by Law 4/1989 is the Plan de Ordenación de los Recursos Naturales i.e., the NRP. This was a novelty that tried to combine two approaches to planning:

a) The older Master Plan, Management Plan or Guide Plan [17] system, collecting the documentation available at the time (without too much detail);

b) A more modern, dynamic and flexible approach that continuously produces a large number of documents, but in an orderly manner, thus allowing its revision and use, etc.

In its summary, Law 4/1989 defines an NRP as a "flexible instrument allowing integrated treatment of areas for conservation of those resources and species whose protection is sought". The importance of NRP's is such that the same Law states that they may not be altered by any other instrument of territorial or physical planning. An NRP is therefore an environmental protection tool that approaches local-area planning from the perspective of the appropriate use of natural resources, and that classifies those areas to be managed under one of the protection systems outlined by the Law.

Any conflict with urban interests should be solved by the NRP. Such conflicts should be few, however, since the land to be protected is usually classified (under different names) as non-building land.

An NRP should also reflect the social tendencies and pressures of the area, which will undoubtedly have an impact on later management.

A Usage and Management Plan (UMP) is the main instrument that develops the information in the NRP. It outlines how the latter will be used to manage the protected area and achieve its goals. This terminology (NRP, UMP) was actually a common feature of Spanish planning before Law 4/1989 was passed, but when it came into force the UMP became subordinate to the NRP.

UMP's were originated by Royal Decree 2676/ 1977, when Law 15/1975 on Protected Natural Areas come into effect. That law required State authorities to take the necessary steps, via a Plan Director (Guide Plan), to safeguard the characteristics and assets motivating the creation of a National Park, to facilitate access to the area for its use and enjoyment, and to prevent those activities that could affect it negatively. The term Usage and Management Plan first appeared in the laws that created (and later reclassified) the National Parks (1975), but it was not actually used in practice until the creation of the Doñana and Las Tablas de Daimiel Parks in 1978. Its institutional use came about with Law 4/1989, although its character was now substantially altered since it had become an adjunct to the NRP. While an NRP is a document for planning the uses of natural resources, the UMP determines how these resources are to be protected. According to Ruiz del Portal [19], the UMP is therefore "conservationist" in character.

Since the UMP regulates the activities of a protected area, reconciling the aims of research, public use and conservation etc., it should be produced by the body whose function it is to manage the area. According to Law 4/1989, Boards of Directors or Patronage Boards may co-operate with park administration bodies in this. Approval of the UMP is up to the appropriate Regional Government (or a Management Commission representing the different Autonomous Regions whose borders a protected area might cross), but it must be ratified by the State authorities. UMP's have a specified life span and must clearly state their aims and priorities, the activities they envisage, and the resources available to these ends.

As specified in its Laws, Spain is politically and legally structured in Autonomous Regions that have produced their own legislation and planning instruments. With reference to National Parks, the pioneering Regions in complementing Law 4/1989 were Catalonia (which produced its own Special Protection Plan and Annual Management Plan) and Andalusia (which produced an Integral Development Plan and Promotion Programme).

As mentioned above, planning criteria changed substantially during the course of the 20th century. Protectionist policies with reparative or corrective intentions designed to repair damage that had already occurred (and which gave no thought to any rational management of the area) eventually gave way to preventive criteria that tried to minimise future damage as much as possible (but which also gave no thought to how the area might be used). Along these latter lines, Carceller [4] wrote "Management of the environment should be based on the principles of preventive and corrective actions... It should try to avoid disturbances or at least prevent disturbances from reaching unacceptable levels rather than trying to repair damage once it has been caused."

Once consensus had been reached that the best way to protect a natural area was through proper planning and management, a great step forward was made. This involved the incorporation of local-area planning techniques, the idea of integrating protected areas, and the introduction of predictive criteria. The latter are understood as criteria for measuring those variables whose modification results in a change in the area over time. They therefore underlie any management plan in line with the needs of the protected area and its users. Finally, up-grading criteria were introduced with the aim of improving the adaptability, ability to respond and/or reversibility of the environment.

The Spanish experience shows that the management activities of a Nature Park should be more than the simple protection of its resources. In France, the planning of Nature Parks focuses particularly on landscape planning and on the improvement of rural life; the conservation of nature is the responsibility of bodies other than the Park. This, however, is not a completely integrated managerial approach. The truth is that protected areas commonly require very complex management involving the integration of many different activities. If goals are to be met, planning the 
management of environmental resources (or other types of heritage) is a necessity.

From a planning point of view, the criteria behind the designations Nature Park, Nature Reserve, Natural Monument and Protected Landscape recognised by Law 4/1989 can be perfectly extrapolated in respect of one other. Nature Parks should be established along with corresponding NRP's. The NRP, or the UMP which develops and establishes the NRP, should also define the administration of the area's resources. In addition, classification of the area under one of the Law's designations implies that certain conditions must be met:

- Detection of the needs of the area to be protected;

- Identification of priorities;

- Listing of the available resources;

- Adoption of programmes;

- Evaluation of decisions taken.

Consequently, the following criteria should inspire the planning process:

- Acting on consensus. Complementation and coordination of political, administrative, sector and local, environmental (conservation) and public (enjoyment) interests.

- Mediation. Continuous integration of existing or foreseeable conflicts (detected through information gathering) over resources, the reconciliation of clashing plans and policies as well as problems caused to industries etc.

- Consultation. Clarifying the bases for decisions made (which should be extensive knowledge of the protected area and current circumstances).

- Monitoring and follow-up. Production of an interactive work system allowing the progressive attainment of stated goals, albeit permitting reconsideration or correction and the incorporation of selfmonitoring mechanisms.

- Development (as a consequence of the above) of the norms and management programmes that make it possible to attain goals and to administer the protected area.

- Maintaining the principles for which the area protection was sought: conservation, restoration and the improvement of natural resources and cultural values.

Management of protected areas ought to be possible with proper conceptual planning, however, the practical application of management plans requires flexibility and the training of qualified personnel who can guarantee that goals will be attained.

\section{Results and discussion}

It is possible to explore different relations between public and traditional use of Nature Parks in order to define a new management model for their public use.

Since the break with the strict conservation policies that lasted until the end of the 20th century, the most important factor in the planning of protected ar- eas has been the large-scale incorporation of the idea of 'public use'.

Society's attitude with regard to respect for the environment, the desire for contact with nature (which is becoming more and more difficult in urban spaces) and a maturing leisure culture (needed to reduce the stress of modern life), have all been factors leading to the growing number of visitors to areas of natural or cultural heritage. Parks, under their different designations, have been in great demand.

A social need has arisen concerning the enjoyment of natural areas - a need that is compatible with the socio-economic requirements of populations living in proximity of protected areas who wish to share the rewards that public use can bring.

From a technical point of view, public use is understood as the facilities, activities, and services to be planned and managed in a protected area, so that visitors are introduced to its natural and cultural values. This will guarantee conservation of the area. Clearly, National Parks are better equipped and better prepared to manage public use, and although there are areas where improvement can be made, they have largely solved the associated problems. Most of the remaining Nature Parks, however, have not been able to adapt to current social demands: neither their governing authorities, their management resources, their facilities nor their infrastructures are capable of meeting such needs.

Tourism and the recreational use of a protected area are factors that, when controlled, can have a great beneficial impact on the socio-economic development of the areas influenced by Parks. The difficulty arises when trying to provide them with what they need to deal satisfactorily with large numbers of visitors, and when trying to make this new use compatible with the interests of the resident population and with the conservation of biodiversity. According to data gathered by the Action Plan for Natural Areas produced by EUROPARC-España, the number of visitors to National Parks in 1984 was 2.4 million - a figure that had more than quadrupled by 1999 . Currently, the protected areas of Spain receive some 30 million visitors per year. Obviously, the material and human resources of these areas have not increased at the same pace. The public use of Parks as well as rural tourism (now very popular) require infrastructures including hotels and other facilities allowing visitors to enjoy their free time. The demand is growing, but local governments in the proximity of Parks often do not know how to meet it or are unable to do so.

The reason for these problems is poor (or even non-existent) planning and inefficient management. As mentioned above, the last ten years have seen some improvement in the discrepancy between the number of parks declared and the number which actually have an NRP, although much remains to be done. This being the case with NRPs, it is easy to imagine the state of management plans. At the same time, the desire of some parks to normalize their situation has 
not been matched by the necessary political will to finance the stated objectives.

According to the Technical Department of EUROPARC-España [12], 42.76\% of Spanish Nature Parks do not have a visitors' centre and many have no mapped-out routes and no information for visitors. Some do not even have adequate sign-posting.

Until recently, tourism in Spain, both domestic and international, has involved mainly the coastline (sun and beaches) and movement towards the interior (countryside and urban areas) has been noticed only to a minor extent.

Nevertheless, the general social tendency towards recovery of natural values and awareness of environmental issues has generated a new type of tourism initially known as rural in Spain - involving the countryside and rural areas. This nature-based tourism, often called ecotourism or nature tourism is the fastestgrowing segment of tourism (WTTC, 2000).

According to Heras [13], each country coins an expression in relation to the singularities of the countryside involving the idea of activities developed in a rural area, and based on the use of human, natural and material resources.

The European Union refers to this term as "the activities developed in farms, agricultural exploitation and activities performed out-of-doors in protected areas (environmentally protected areas, green tourism) and the leisure activities carried out in urban and rural areas, if they imply something other than simply visiting a place".

The fundamental aspects of this type of tourism and on which its expansion and consolidation depend are the following:

- improvement of the quality of the services, in relation to consumer comfort;

- implementation of these services with a variety of leisure activities;

- controlled fees maintaining a high quality/price ratio;

- adapting equipment and resources to maintain a more profitable "round-the-year" offer.

Townspeople are fascinated by the idea of going "back to nature" and enjoying nature (fauna, flora and country views), bike riding, hiking or the variety of extreme sports etc. This coincides with a new way of understanding and spending leisure time that require planning and management of natural resources, in order to guarantee their public use and softening the impact these activities can produce on the environment. The tourist industry has made an effort to integrate this new management of protected areas in general, and in particular of the Nature Parks. The actions undertaken in this sector prove it.

The sustainability aspects of nature tourism and ecotourism should include specific elements such as conservation, community involvement, interpretation and education, as well as environmental management practices [21]. From this point of view, the planning and management of a protected area must consider both the need for conservation expressed by the local population and the requests correlated with public use. They must analyse the possibility of conflict and its consequences and look for alternatives; in effect, they must try to piece together the puzzle that a protected area is. The difficulty of this task increases dramatically when trying to reconcile the traditional interests of the area with public use and enjoyment, and when dealing with the many new factors such activities might introduce [16].

The key to success could reside in considering public use as just another productive function of a protected area, although subordinate to and conditioned by other activities linked to its resources and their exploitation. The environmental protection of an area can never lead to the abandonment of its productivity or to prohibition of the activities carried on inside it [2]. This position strengthens the idea that protected areas should be integrated into their larger environments, and it clearly defends the idea of their use and exploitation. Public use, understood as the recreational use made of the area by its visitors, is also a productive use to be incorporated into an area. So it would make no sense at all to exclude the public from the production process or to deny them access. However, such access should be compatible with conservation of the area, and public and recreational use of protected areas requires rules and regulations designed to minimize its impact.

At the beginning of the planning process, the plurality of interests to be accommodated have to be set. Such planning entails three major areas of interest:

- Local interests (detected in the analysis of resources and in the plans of the various different industrial sectors);

- Interests more directly linked to the administrative authorities, i.e., the more 'institutional needs, e.g., conservation of the protected area and research etc.;

- Strictly public interests, i.e. those of the visitors. These will entail investigating the Park's (current and potential) reception capacity, the consequent analysis of existing infrastructures, how the area's resources and their vulnerability will be affected, and the planning and programming of public use activities.

Involvement of the resident population from the inception of the planning process will surely reveal any conflicts of interest related to the traditional use of the area. At the same time, the local population will be constantly informed, and will become aware of the economic and social benefits that protection of the area could bring.

It is in the management of public use, however, that efficiency of planning is most easily measured. Careful planning of public use, in line with local traditions, should provide adequate protection of the area [16].

In this process the infrastructures should not be considered an aim as such. Rather, they are the means for implementing management of public use. 
Thus, a survey of the present and future reception capacity of a Park will give rise to a list of shortages and resource deficiencies. The planning of new areas and uses will therefore confirm or deny the validity of the existing infrastructures and buildings to be used for the recreational activities.

Nevertheless, the final zoning programme will depend on the detailed analysis of the capability of the area to withstand that specific use, as well as on the effect and impact of the programme on the quality and fragility of the environment.

Aramburu [1] defines quality as the value due to which an asset is worthy of protection, whereas fragility or vulnerability is its capability of being deteriorated; it is a generic concept related to the system's reception capacity. In addition, García Moruno [10] defines visual fragility as "the possibility of change occurring in the landscape when it is subject to a specific use. It determines the degree of deterioration affecting this landscape".

These ideas can be applied perfectly to protected areas in relation to the physical conditions as the landscape is one of the resources, and fragility is a generic concept.

In later years the preoccupation with minimizing the impact of human activities on the environment has increased due to a greater social awareness of the need to respect the environment. In other non-rural areas, this need is partially covered by the characteristics of the urban environment, which is a very humandependent environment capable of absorbing the negative aspects in a "natural" way.

The increase in rural tourism and the need to be in contact with nature, together with the recovery and transformation of traditionally agricultural areas or forests for leisure activities have become more significant. As a result, there is a need to maintain the functionality of rural areas as well as to lower the perception of the anthropic landscape. There are many areas which survive with the exploitation of soil resources, and in which modification of the landscape with the presence of buildings and constructions is inevitable. New materials and construction techniques have led to the proliferation of infrastructures and equipment, which in many cases break up the original landscape harmony. Thus, comprehension of environment, landscape and folklore have shaped the concept.

But landscape is at the same time the most appreciated parameter in the appraisal of a protected natural area [7], something needing further analysis.

Concern for the environment and landscape is now part of the new sensibility of administrative authorities, and as an example, we can refer to the European Landscape Convention [5] signed by the members of the European Council and listing all the causes of the need for such a document.

The management of public use has to link together the plans that have been developed and the principles of "well-doing", the good practices related to sustainability.
The following are proposed as the principles that should underlie this management.

- The principle of submission. Actions should always be consistent with prior planning.

- The principle of shared responsibility. All the different parties involved in plans and programmes should be responsible for management decisions and actions.

- Principle of instrumentation. This involves the proper application of management criteria and instruments (preventive, corrective, curative, predictive and encouraging [aimed at improving the adaptability, capacity to respond and reversibility of the natural environment]).

- Principle of sustainability. The use and development of resources should follow solid criteria. All activities should be integrated into the environment.

- Principle of globality. Local actions should always incorporate a global perspective, which integrates the protected area into the surrounding territory.

- Principle of subordination. Problems should be solved at the lowest level of responsibility possible.

- Principle of economy. "Economic is ecological" and vice versa.

- Principle of profitability. Investments, adjusted to management and usage plans, should try to internalize the costs of exploiting and developing resources, seeking profitability compatible with sustainability.

- Principle of quality. Quality in the service offered should be a goal in all decisions. Follow-up and evaluation is vital if quality is to be achieved.

\section{Conclusions}

The definition of a Nature Park maintains the idea of a protected natural area whose management should guarantee its conservation and preserve its resources, yet allow an appropriate reconciliation of traditional and public uses (including public enjoyment). Experience shows that this spirit has not always been maintained. Sometimes these areas have been converted into areas of mere public use (peri-urban parkland) although other areas have become National Parks or Reserves. Anyway, it is not possible to state that there has always been a balance between the three major issues in the management of Nature Parks: promoting conservation, developing the compatible use of resources, and stimulating public use.

This research has shown that there are weaknesses in the concept and use of the original designation ' $\mathrm{Na}$ ture Park' that Law 4/1989 has not been able to solve. This specific designation was eliminated by this law (although in practice the epithet often remained), and these areas were reclassified under other designations that afforded greater protection. Unfortunately, confusion and poor practices continue under the new system. In some cases the creation of a Nature Park has 
been used as a way to achieve rapid protection of an area without the necessary planning. On other occasions, the designation has been used as if it meant 'National Park' but at a regional level. Yet other parks have been declared as such without much justification.

Weaknesses exist in the management models for these protected areas; indeed, good management is often lacking. Almost $60 \%$ of Nature Parks have no approved NRP or UMP. The two most common deficiencies are a one-dimensional management focus, i.e., management that does not take the different activities that could be practised in these areas (e.g., conservation, public use and enjoyment) into account, and a management model based on technical documents which does not consider the wishes of the local population or of the broader community.

The concept of Nature Parks should be accompanied by an improvement in the concept of NRP's and UMP's, along with the development of new management tools such as sector plans or specific programmes. As mentioned above, if goals are to be attained, management tools, and in particular NRP's, should take different points of view into account. Models are required that make management criteria more homogeneous and that enable follow-up and evaluation of actions taken.

In spite of the weaknesses described, Nature Parks are important conservation assets. They are of huge social value and are regarded as important attractions by the general public [7]. The great dissatisfaction that both residents and visitors often show with regard to their management must, however, not be ignored.

Special attention should be paid to the idea that, given their isolation, Nature Parks need to be more than simple instruments of conservation. Rather, they should be seen as social intervention programmes that consider the needs of different communities, even involving them from the very beginning of planning. Planning and management should consider compensation for local populations, and be linked with programmes of sustainable development in the areas of which they are part.

Nature Parks are favourite places for learning, dealing with nature, and just getting away from it all [7]. The quality of a visit is closely related to the quality of the Park itself, to the information received on the natural resources of the area and, above all, to the explanatory facilities available. Most people regard a visit to a Nature Park as a positive experience, but there are enormous differences between the facilities available for public use at different parks. Thus, an adequate and consistent programme for monitoring and evaluating the quality of Park visits need to be developed.

\section{References}

[1] Aramburu M.P. et Al., Guía para la elaboración de estudios del medio físico. Madrid: MOPU; (1981).
[2] Baigorri A., De la Naturaleza social de la Naturaleza; In M. Pardo (ed.), Sociología Medioambiental. Estado de la cuestión. Madrid: Fundación de los Ríos; (1999).

[3] Brown J., Mitchell N., Beresford M., The protected landscape approach: linking nature, culture and community; IUCN World Commission on Protected Areas; (2005).

[4] Carceller i Roque X., Instrumentos de planificación y mecanismos de gestión para la mejora del medio ambiente. Los espacios naturales protegidos; In El impacto ambiental en el planeamiento urbanístico; Madrid: Fundación Cultural COAM; (1996).

[5] Consejo de Europa, Convenio Europeo del Paisaje, Florencia, 20 de octubre de 2000; (1995).

[6] Corraliza J.A., Percepción y gestión del medio natural. Nuevas perspectivas. Boletín de la Real Sociedad Española de Historia Natural (Actas); 97; (2000); 35-44.

[7] Corraliza J.A., García navarro J. y Valero E., Los Parques Naturales en España: conservación y disfrute. Madrid: Fundación Alfonso Martín Escudero, Ediciones Mundi-Prensa, (2002).

[8] Europarc-España, Plan de Acción para los Espacios Naturales Protegidos del Estado Español. Madrid: Fundación Fernando González Bernáldez; (2002).

[9] Filpa A., Romano B.; Pianificazione e reti ecologiche, Planeco, Gangemi Ed., Roma; (2003).

[10] García Moruno L., Criterios de diseño para la integración de las construcciones rurales en el paisaje. Tesis doctoral, sin publicar. Madrid: ETSIAM; (1998).

[11] Generalitat de Catalunya, Patrimonio Natural: El Plan de Espacios de Interés Natural de Cataluña. http://www.gencat.es/mediamb/pn/epein.htm

[12] Gómez-Limón García J., Oficina Técnica de EUROPARC-España; De la declaración a la gestión activa: Los Espacios Naturales Protegidos del Estado Español en el umbral del siglo XXI. Madrid: Fundación Fernando González Bernáldez (2000).

[13] Heras V., El turismo en el desarrollo rural. Boletín Agrario (Consejería de Medio Ambiente de la Comunidad de Madrid); 21; (2000); 16-19.

[14] InTERNATIONAL Union FOR CONSERVATION OF NATURE, Guidelines for Protected Areas Management Categories. CNPPA with assistance from WCMC. IUCN; Switzerland; (1994).

[15] Jongman R., Pungetti G., Ecological Networks and Greenways. Concept, design, implementation. Cambridge University Press (2004).

[16] Koontz T., The farmer, the planner, and the local citizen in the dell: how collaborative groups plan for farmland preservation.; Landscape and Urban Planning; 66; (2003); 19-34.

[17] Miller K., Planificación de Parques Nacionales para el desarrollo en Latinoamérica. Madrid: Fundación para la Ecología y el Medio Ambiente (FEPMA), (1980).

[18] Noe Francis P., Hammitt William E., Bixler Robert D., Park User Perceptions of Resource and Use Impacts Under Varied Situations in Three National Parks; Journal of Environmental Management; 49; (1997); 323-336.

[19] Ruiz del Portal Mateos A., Conservación de los re- 
cursos naturales. PORN y PRUG, dos instrumentos planificadores complementarios. Urbanismo COAM, Revista del Colegio Oficial de Arquitectos de Madrid; 28; (1996); 6-11.

[20] White P.C.L., LovetT J.C., Public preferences and willingness-to-pay for nature conservation in the North York Moors National Park, UK; Journal of Environmental Management; 55; (1995); 1-13.

[21] World Tourism Organization, Sustainable Development of Ecotourism - A Compilation of Good Practices. WTO; (2001).

\section{SUMMARY}

The great change in the management of protected areas over the last forty years has been a shift in focus from what happens within Park boundaries to what happens outside them but necessarily influences what goes on inside them. Once treated as treasures to be isolated and protected from all interference, the present consensus is that Nature Parks should be considered an integral part of the economic, ecological and social dimensions of the local area to which they belong. This research paper proposes a working model for Park managers and planners able to reconcile the need for conservation with sustainable development of the area. Public use and enjoyment of protected areas is not only compatible with conservation but is essential to both preservation and to integration of the Park into its local area. Making conservation compatible with traditional uses of resources and with public use and enjoyment, encouraging all the parties concerned to be involved in planning and decision-making, and inculcating a 'culture of conservation' may make the goal of preserving protected areas easier to attain.

Key words: Nature Parks, protected areas, resource planning, landscape management, ecotourism. 